\title{
„Gúzsba kötve táncolunk” Zsugorodás és a kontroll leszivárgásának politikai gazdaságtana magyarországi középvárosokban
}

\author{
Jelinek Csaba \\ https://doi.org/10.51624/SzocSzemle.2020.2.6 \\ Beérkezés: 2020. 06. 05. \\ Átdolgozott változat beérkezése: 2020. 09. 07. \\ Elfogadás: 2020. १०. 27.
}

\begin{abstract}
Összefoglalás: A városi zsugorodás politikai gazdaságtani megközelítéseiben fontos szempont a zsugorodó városok mozgástere a tágabb, több léptéken zajló strukturális folyamatok fényében. Jelen tanulmány négy magyarországi középváros költségvetésén keresztül elemzi azt, hogyan változott az elmúlt években a kis- és középvárosok lehetősége arra, hogy meghatározzák jövőbeli fejlődési pályájukat. A tanulmány első része röviden összefoglalja az elmúlt évtized központosítási tendenciáit, majd megállapítja, hogy az önkormányzati adósságrendezéssel együtt járó önkormányzati reformok eredményeképpen a központi kormányzat egyre nagyobb kontrollt tud kifejteni a települési önkormányzatok felett. Miközben a költségvetési főösszeg a vizsgált városok esetében radikálisan lecsökkent, a helyi adóbevételek relatív súlyának növekedése a költségvetésen belül nem növelte a városok valós mozgásterét, hiszen a gazdaságfejlesztés területe is rendkívül centralizált. Bár az EU-s fejlesztési források és a közfoglalkoztatási programok súlya a városi költségvetéseken belül jelentősen megnőtt, ezek központi elosztása, illetve specifikus célzása a helyi marginalizált lakosság kontrollját segíti elő. Ezt a folyamatot a kontrollmechanizmusok „leszivárgásának” nevezem. Ezeken kívül a „pofapénz” gyakorlata is rávilágít arra, hogy az önkormányzati rendszeren belül lévő feszültségek kezelésének jelenleg leghatékonyabb módjai nem formális intézményi megoldásokon, hanem informális lobbitevékenységeken alapulnak. Összességében a fenti változások a zsugorodó középvárosok esetében egy szűk mozgásteret vetítenek előre, ahol a zsugorodó tendenciák változása leginkább a tágabb politikai és gazdasági változások függvénye.
\end{abstract}

Kulcsszavak: zsugorodó város, önkormányzati költségvetés, városi kormányzás, centralizáció, kontroll

\section{Bevezetés}

Az elmúlt évek zsugorodó városokról szóló nemzetközi szakirodalmában egyre erőteljesebben jelentkezik az a törekvés, amely a városi zsugorodás jelenségét egy tágabb politikai-gazdaságtani keretben igyekszik értelmezni (Aalbers-Bernt 2018;

1 A kutatást a „Helyi közpolitikák és a marginalitás (újra)termelődése hanyatló városokban” (119465) címú, NKFIH-kutatás keretében végeztük. A kutatáshoz kapcsolódó terepmunkákban részt vett: Jelinek Csaba, Jónás Marianna, Kovai Cecilia, Németh Krisztina, Pulay Gergely, Váradi Monika Mária, Vigvári András, Virág Tünde és Zolnay János. Kutatásvezető: Virág Tünde. 
Bernt 2015). Jelen lapszám elemzési kerete szerint ez azt jelenti, hogy a városi zsugorodás sosem kizárólag önmagában érdekes; sosem értelmezhető kizárólag a városok léptékén. A zsugorodó városok jelensége minden esetben olyan tünet, amely mélyebb, több léptéken zajló politikai-gazdaságtani mozgásokban gyökerezik. Sőt ahogy azt a lapszám bevezetőjében kifejtettük (Jelinek-Virág 2020), a zsugorodás a legtöbb esetben a periferializáció többléptékű folyamatának egy specifikus esete.

Aalbers és Bernt (2018) tanulmánya a zsugorodás jelenségének vizsgálatához egy olyan politikai-gazdaságtani összehasonlító keretet javasol, amely egyszerre érzékeny kontextusokon átívelő közös témákra - mint például a nemzetállami, az EU-s, vagy a globális lépték hatása a zsugorodó városok kormányzására -, illetve helyi történeti és intézményi specifikumokra, mint például a zsugorodó városok politikai és gazdasági szereplői által létrehozott sajátos „fejlesztési koalíciók”. Terjedelmi korlátok miatt jelen tanulmány nem vállalkozik egy szélesebb nemzetközi összehasonlításra, ehelyett a tágabb kutatásban vizsgált négy zsugorodó városra, illetve ezen keresztül a nemzetállami és a városi lépték közötti változó viszonyokra összpontosít. Ennyiben jelen elemzés nem pusztán a zsugorodó városok szempontjából tesz releváns állításokat, hanem arról a tágabb kontextusról is, amely meghatározza a zsugorodó - és bizonyos megkötésekkel a nem zsugorodó - városok vezetőinek a jövőbeli mozgásterét. A tanulmány kiinduló kérdése az, hogy mekkora mozgástérrel rendelkeznek a mai Magyarországon a zsugorodó kis- és középvárosok abban, hogy meghatározzák saját fejlődési pályájukat, és hatással legyenek a helyi társadalmi és gazdasági folyamatokra. Mennyiben a tágabb strukturális mozgások, és mennyiben a helyi döntéshozói akarat szabja meg egy zsugorodó magyar középváros fejlődési pályáját? Mekkora a mozgástere a helyi döntéshozóknak?

Ezek a kérdések nem pusztán elméleti szempontból fontosak. Azáltal, hogy a városi zsugorodás jelenségének holisztikusabb megértéséhez is hozzájárulnak, döntéshozói beavatkozásokhoz is biztosabb alapot adnak. A zsugorodó városokról szóló alkalmazott kutatások egy része ugyanis a lehetséges önkormányzati válaszokra fókuszál, és ezen belül keresi az „okos zsugorodás” (smart shrinking) vagy a „helyes méret megtalálásának” (right-sizing) közpolitikai stratégiáit (Hackworth 2015). Ezek azonban csak akkor lehetnek valóban sikeresek és társadalmilag előremutatóak, ha a tágabb politikai-gazdaságtani összefüggéseket is figyelembe veszik (vö. Coppola 2019), és nem pusztán a helyi megszorító politikák eufemisztikus elnevezései maradnak.

A zsugorodó önkormányzatok mozgásterével kapcsolatos kutatási kérdést vegyes módszertannal fogom vizsgálni. Mivel a politikai-gazdaságtani megközelítés központi jelentőségű a fent hivatkozott elméleti megfontolások miatt, ezért a módszertan egyik része kvantitatív, és az önkormányzatok számára rendelkezésre álló gazdasági és politikai mozgástér változásának a megértéséből indul ki. Ebben a tanulmányban ezt a változást leginkább az önkormányzatok költségvetésén keresztül, pontosabban a bevételi és a kiadási oldal változásának az elemzésén keresztül fogom bemutatni.

A módszertannak ez a kvantitatív része számos kihívást rejt magában. Egyrészt az államháztartási számvitel szabályainak, illetve a különböző jogcímeken folyósított köz- 
ponti támogatások szabályozásának gyakori változása miatt nehéz hosszabb és komplexebb idôsorokat készíteni. Másrészt amikor ez lehetséges, gyakran nehezen értelmezhető grafikonok születnek, amelyekre a tipikus magyarázat az önkormányzatok „kreatív könyvelése”. Bizonyos tételek magyarázatához elengedhetetlen olyan „belsős” adatközlők segítsége, akik átlátják a számok mögött meghúzódó döntéshozói akaratot, illetve a változó szabályozói környezetre adott specifikus helyi válaszok logikáját.

Emiatt tűnt elengedhetetlennek a kvantitatív módszerek kvalitatív eszközökkel történő kiegészítése. A nemzetközi szakirodalomban az 1970-es évek óta létezik az önkormányzati költségvetések kritikai elemzése, amely a fősodorbelinek nevezhető számviteli szempontok mellett magát a költségvetést is mint társadalmi terméket, mint érdekharcok eredőjét tekinti (Heclo-Wildavsky 1981; Péteri 1992; Wildavsky 1975). Ebben a kutatási hagyományban fontos módszertani eszköz a döntéshozókkal, illetve a hivatalnokokkal készített interjú. A kutatásunkban így az önkormányzatok költségvetési rendeletei és zárszámadásai mellett az ilyen típusú interjúk is nagy hangsúlyt kapnak².

A tanulmány következő szakaszában bemutatom a magyarországi önkormányzati rendszer elmúlt három évtizedének a rövid történetét, különösképpen a 2010 utáni központosítási törekvéseket. A cikk fő állítása szerint az elmúlt évtized reformtörekvései miatt egy sajátos városi kormányzási rendszer alakult ki Magyarországon, amely nemcsak a központi kormányzat kontrollját növelte a városi önkormányzatok felett, hanem a városok kontrollját is az alacsonyabb osztályhelyzetú lakóik felett. A kontrollfunkciók „leszivárgásának” a folyamatát ezután a következő szakaszban a terepkutatásunk során gyűjtött empíria alapján mutatom be. Négy magyarországi középváros költségvetését a közhatalmi bevételek és a helyi adók, az európai uniós finanszírozásban megvalósult fejlesztési projektek, a közfoglalkoztatási programok, illetve a „pofapénz” jelensége mentén elemzem. A tanulmány végkövetkeztetése, hogy az általunk vizsgált zsugorodó városok fiskális mozgástere szinte minden dimenzióban csökkent, kivéve a helyi marginalizált csoportok kontrollálására képes közpolitikai eszközöket. Így bár - az egyik interjúalanyunk kifejezését használva - a zsugorodó városok „gúzsba kötve táncolnak”, a korábbiaknál nagyobb terük van a területükön élő szegényebb csoportok „gúzsba kötésére”.

\section{Egy új kormányzási modell értelmezései}

Ahogy azt a lapszám bevezető tanulmányában is bemutattuk (Jelinek-Virág 2020), Magyarország népessége az 1980-as évektől folyamatosan csökken, sőt egyes városok esetében már az 1970-es vagy akár az 1960-as évektől. A zsugorodó tendenciákkal jellemezhető elmúlt 4-5 évtizedben két alkalommal is - a rendszerváltáskor, illetve 2010 után - paradigmatikus változások történtek a hazai önkormányzati rendszer-

2 A tágabb kutatás módszertanáról lásd a jelen lapszám bevezetőjét (Jelinek-Virág 2020). Szűkebben az önkormányzati költségvetések témájában a kutatás terepeként szolgáló négy városban a városvezetőkkel, a jegyzőkkel, a költségvetésért és pénzügyekért felelös hivatali egységek vezetőivel, illetve dolgozóival, valamint helyi vállalkozókkal és önkormányzati vállalatok vezetőivel készítettünk interjúkat, de a téma több más interjú során is elökerült. Az elemzés mindezekre a forrásokra épít. 
ben, amelyek nagyban meghatározták a zsugorodó városok vezetőinek mozgásterét. Az 1980-as évektől egy decentralizációs tendenciát azonosíthatunk, amely az 1990ben elfogadott, új önkormányzati törvénnyel csúcsosodott ki³. Mára már talán közhely, hogy az 1990-es önkormányzati törvény - Pitti Zoltán (2000) szerint a „kompromisszumok” és a „félig rendezett ügyek törvénye” -, illetve ennek az új decentralizált rendszernek a későbbi korrekciói súlyos strukturális anomáliákat teremtettek. Már az 1990-es évek elején láthatóak voltak az új önkormányzati rendszer alapvető hiányosságai - mindenekelőtt a forráshiány és az önkormányzatok közötti polarizációt elősegítő szabályozások -, amelyek aztán végig jelen voltak a következő két évtizedben (Bird-Wallich-Péteri 1995). Bár ebben az időszakban végig a téma szakértőinek napirendjén volt az önkormányzati rendszer és azon belül az önkormányzati finanszírozás reformja (Vigvári 2005), szisztematikus változások nem történtek, csak egyfajta „salátatörvénykezés” (Vigvári 2007: 178). Ez elsősorban az önkormányzatok költségvetési hiányának szisztematikus újratermelődésében, illetve később, a 2000-es évek folyamán az ebből következő tömeges eladósodottságukban érhető tetten.

A rendszerváltás utáni tizenöt évben az önkormányzati hitelállomány az éves költségvetéshez viszonyítva az ötszörösére emelkedett (Csiszárik-Kocsir 2008), és nagyrészt az önkormányzatok mủködési hiányának az elfedését szolgálta. Nominálisan az önkormányzati hitelállomány majdnem négyszeresére emelkedett 2001 és 2008 között, emellett pedig 2006 és 2008 között a kibocsátott önkormányzati kötvények - amelyek egyfajta bújtatott hitelezésként múködtek, hiszen szinte kizárólag a kibocsátó bankok vásárolták őket, viszont a hitelekkel ellentétben kívül estek a közbeszerzési törvény hatályán - nominális értéke 27,4 milliárd forintról 436,5 milliárd forintra nőtt (Vigvári 2009). 2008-ban ráadásul az összes önkormányzati kötelezettség fele devizában volt denominálva, azaz ekkora állományt (több mint 600 milliárd forintot) érintett a 2008-as globális válság során tapasztalt forintgyengülés. Hasonlóan a lakossági devizahitelekhez, az árfolyammozgások kockázatai itt is a hitelfelvevőre (azaz az önkormányzatokra) hárultak, ami katasztrofális állapotot teremtett számos önkormányzat költségvetésében a 2008 utáni években (Lentner 2014).

A 2010 utáni önkormányzati reformok központi eleme az önkormányzatok adósságának több lépcsőben történő „szanálása” volt, azaz a központi kormányzat általi átvállalása vagy a törlesztést lehetővé tevő célzott támogatások folyósítása. Összességében 2011 és 2014 között 2078 önkormányzat esetében 1369 milliárd forint (a GDP 4,2\%-a) értékben történt kormányzati adósságrendezés (Bethlendi-Lentner 2019). Azonban mind a témáról publikáló szakértők, mind az interjúalanyaink gyakorlatilag kivétel nélkül minden kontextusban úgy interpretálták ezt a közpolitikai döntést, hogy a kormány az adósságrendezésért cserébe az egész önkormányzati rendszert a saját politikai elvei szerint szervezte újra. Egyes szerzők elemzése szerint az önkormányzatok eladósodása önmagában nem is indokolta volna a korábbi

3 1990. évi LXV. törvény a helyi önkormányzatokról. 
decentralizált rendszer gyökeres megváltoztatását (Horváth-Péteri-Vécsei 2014); ebből arra is következtethetünk, hogy az önkormányzati rendszer reformját a pénzügyi megfontolásokon túl erőteljes politikai víziók is motiválták.

Ezt az is alátámasztja, hogy a magyar önkormányzati rendszerben bekövetkező paradigmaváltást nemcsak az önkormányzati pénzügyek radikális átszervezése, hanem az önkormányzati feladatok és funkciók átalakítása, illetve tágabban az önkormányzatok politikai szerepének az újraírása is jellemezte. Ezeknek a változásoknak egy jelentős része már 2010 előtt és különösen a 2008-as válság után megindult, ilyen szisztematikus átalakításra azonban 1990 óta nem volt példa. Az önkormányzatok köznevelési, oktatási, egészségügyi, államigazgatási funkcióinak jelentős részét elvonták és központosították (Hegedüs-Péteri 2015); a fejlesztési források elosztásának intézményrendszerét átalakították és centralizálták (itt leginkább az EU-s források elosztásának intézményrendszerére kell gondolni, lásd pl. Józsa 2016); az önkormányzatok és a helyi állampolgárok közötti viszony befolyásolásának és különösképpen a helyi alsóbb osztályhelyzetú állampolgárok menedzselésének az eszköztárát viszont a közmunkaprogram kiterjesztésével, illetve a szociális segélyezés radikális - a munkaalapú társadalom ideológiájával legitimált - átalakításával jelentősen átszervezték (Kováts 2016; Scharle-Szikra 2015; Szikra 2014).

Ennek a korszakváltásnak az egyik tipikus interpretációjára jó példa a Pálné Kovács Ilona által szerkesztett kötet (Pálné Kovács 2016), amelyben a szerzők a centralizációs tendenciákat bírálják, miközben „búcsút vesznek” az impliciten ideálisabbnak tartott decentralizált modelltől. Egy másik tipikus interpretációra szolgál példaként Hegedüs József és Péteri Gábor cikke (Hegedüs-Péteri 2015). Eszerint az érvelés szerint decentralizált és centralizált rendszerek is lehetnek hatékonyak, amennyiben megfelelő érdekeltségi viszonyok szabályozzák a rendszert; kellőképpen átlátható az igazgatási struktúra; és erős a jogbiztonság mértéke. Míg Hegedüs és Péteri végkövetkeztetése szerint a 2010 utáni centralizált rendszer ezeknek a feltételeknek nem felel meg, addig a 2010 előtti decentralizált korszakot úgy jellemzik, mint egy, „a korábbiakban szerves módon fejlődő helyi önkormányzati és közszolgáltatási rendszert" (Hegedüs-Péteri 2015: 90). Sőt ezt a rendszert „a magyar társadalom modernizációjával” feleltetik meg, amely a 2010 utáni átalakítások ,áldozatául esett”.

Ennek a decentralizációpárti, illetve modernizációelméletekbe lehorgonyzott interpretációnak az alternatíváját adja Vigvári András - még a 2010-es változások előtti - megközelítése (Vigvári 2008), amely Hegedüsékhez hasonlóan nem önmagában a decentralizációt tartja egy kívánatos önkormányzati rendszer alapjának. Azonban Hegedüséktől eltérően nem merül ki az elemzés a politikai-intézményi feltételek számbavételében, hanem a rendszer lényegét a pénzügyi, elosztási, gazdasági viszonyok struktúrájában keresi. Ezen az alapon jut Vigvári arra a megállapításra, hogy a 2010 előtti önkormányzati rendszer legnagyobb problémája a „szubszidiaritás nélküli decentralizáció" volt, azaz a névleg demokratikus intézményrendszer kialakítása megfelelő pénzügyi eszközök delegálása nélkül. Kicsit átfogalmazva 
Vigvári álláspontját: míg 1989 után a politikai demokrácia jelszavának megfelelően egy decentralizált rendszert hoztak létre, addig a gazdasági demokrácia feltételeinek a kialakítása teljesen háttérbe szorult.

2010 után azonban egy újfajta kormányzási modell épült ki, amelynek a középpontjában - meglátásom szerint - a kontrolláló mechanizmusok, illetve az ezek „leszivárgását” elősegítő intézményrendszerek kiépülése áll. Egyrészt a helyi önkormányzatok mozgástere radikálisan beszúkült, korábbi feladataik jelentős részét elvonták, és ezzel párhuzamosan a költségvetésük is jelentősen lecsökkent, nagyjából megfeleződött. Ahogy ezt a későbbi részekben bemutatom, nem pusztán a költségvetés zsugorodásából, hanem a fejlesztési források elosztásának új rendszeréből is következik a helyi önkormányzatok központi kormányzattól való növekvő függése, és ezen keresztül egy erősödő kontrolláló mechanizmus térnyerése.

Másrészt, ezzel párhuzamosan, a helyi önkormányzat és az állampolgárok viszonya is átalakult. A közmunkaprogram bővítésén, az állami normatíva alapján finanszírozott szociális segélyezési rendszer felszámolásán és az európai uniós fejlesztési források egy részének specifikus célzásán keresztül a helyi döntéshozók olyan eszközöket kaptak a kezükbe, amelyek a helyi lakosság marginalizált részének erőteljesebb társadalmi kontrollját teszik lehetővé (vö. Jelinek-Pósfai 2019). Összességében tehát a központi kormányzat felől az önkormányzatok felé, illetve az önkormányzatoktól az állampolgárok felé irányuló kettős kontroll kiépülő intézményrendszerén keresztül a helyi önkormányzatok egyre inkább olyan társadalmi funkciót töltenek be, amelyben a központi kormányzat egyenlőtlenségeket növelő gazdaság- és osztálypolitikájának a helyi negatív következményeit menedzselik a számukra lehetővé tett szűk korlátok között, valamint korlátozott számú eszköz segítségével. Bár ez a kontrolláló funkció nem teljesen új, hiszen például a Szalai Júlia által leírt „jóléti fogda” intézményrendszere is értelmezhető az önkormányzatok erős kontrollfunkciójának a korábbi időszakban történő kiépüléseként (Szalai 2004, 2005, 2007), a 2010 utáni rendszer azonban a „jóléti” elem szisztematikus kiiktatásával, illetve a szűkebb szociálpolitikai alrendszeren túli eszközök áthangolásával ebben is új dimenziót jelent.

Ez az újonnan megerősödő funkció értelmezhető a társadalmi kontroll és az autoriter kormányzás egyfajta „leszivárgásaként”, amely végső soron a társadalmi egyenlőtlenségek növelését és ezek mintázatainak a megszilárdítását okozza. A hazai középvárosok zsugorodásának a szempontjából ez egy meglehetősen leszúkült mozgásteret jelent, ahol az önkormányzatok többségének a valós mozgástere a zsugorodásból eredő helyi feszültségek különböző kontrolláló eszközökön keresztüli kezelése marad a zsugorodást kiváltó alapvető okok megszüntetése helyett.

\section{Négy magyarországi középváros költségvetése}

A rendszerváltás óta az önkormányzati kiadások GDP-arányosan nagyjából megfeleződtek Magyarországon (Czirfusz-Jelinek 2019). Ebben az időszakban a jelenlegi 
EU-tagországok közül Magyarországon csökkent a legnagyobb mértékben az önkormányzatok lokális autonómiája (Ladner-Keuffer-Baldersheim 2016). A KSH adatai alapján 2010 és 2018 között az összes kormányzati kiadáson belül az önkormányzati alszektor kiadásai 25,35\%-ról 14,04\%-ra csökkentek. Az országos folyamatokkal összhangban az általunk vizsgált négy város éves kiadásai is nagymértékben csökkentek, 2010 óta nominálisan nagyjából megfeleződtek. Ez minden esetben a már fentebb részletezett feladatelvonások következménye.

\section{1. ábra: Négy város kiadásai}

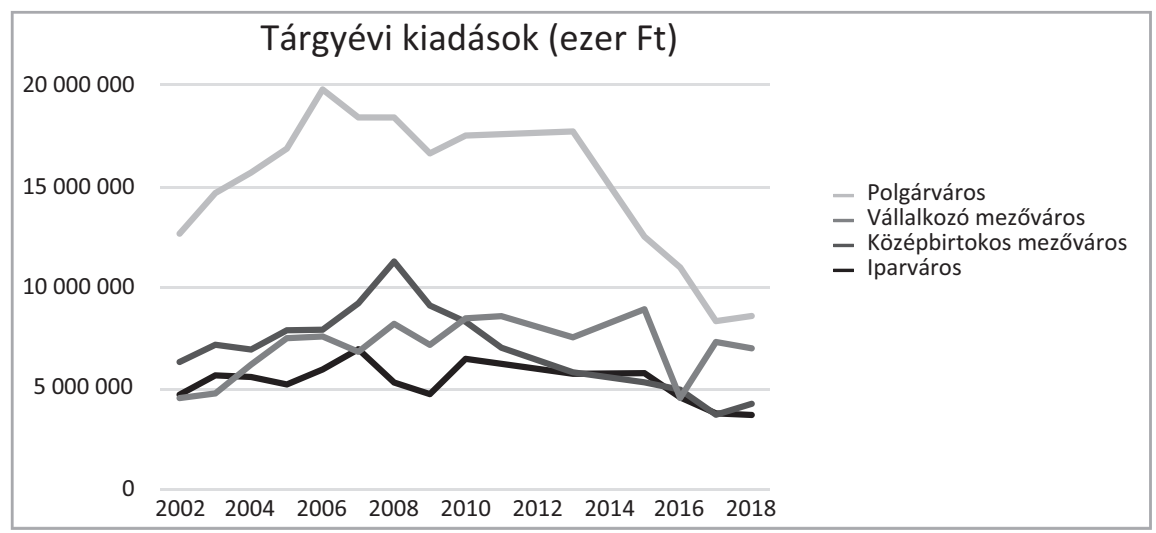

(Forrás: TEIR és zárszámadási rendeletek)

Az önkormányzati költségvetés szűkülésének értékelésekor a legtöbb esetben az interjúinkban is felmerült a korábbi önkormányzati adósságok kérdése. Két város esetében is elhangzott, hogy a kormányzati adósságkezelés nélkül a város nagy bajban lett volna. Az egyik alpolgármester így fogalmazott: „Ha egyévvel később történik a konszolidáció, akkor a 250 milliós éves kamat az árfolyamveszteség miatt 400 millió lett volna [...]. Nekünk az utolsó pillanatban jött, és nagyon jól jött, mert a korábbi két évet tudtuk törleszteni, de a következő évvel problémák lettek volna". Ezzel szemben az interjú más részeiben az adósságkezelés következményei, azaz a feladatelvonások, illetve a további hitelfelvétel központi engedélyhez kötése már kritikusabb színben tűntek fel: „Ami bennünket hátrányosan érintett a kormány részéról, az globálisan az ország szempontjából jó, de nekünk nem annyira jó. Azért nem szivesen ócsárolnám a mi kormányunkat, [...] ilyen szempontból tompítok [...]. Azért nyilván van egy csomó olyan intézkedés, amely az ország szempontjából első osztályú, de városunk szempontjából nem volt mindig jó." A két idézet összeolvasva arra utal, hogy érdemes az adósságkezelés amúgy pozitívként értékelhető közpolitikáját tágabban, az önkormányzati rendszer központosításával együtt vizsgálni.

Az adósságkezelés egy további problémás pontjára világított rá egy másik város vezető tisztségviselője, illetve a város víziközmű-hálózatát üzemeltető cég vezető- 
je. Ebben a városban a 2000-es évek végén a helyi politikusok nyomására a térség önkormányzatainak többségi tulajdonában lévő víziközmű-cég részt vett egy uniós pályázaton, amely néhány, korábban nem csatornázott terület csatornázását finanszírozta meg 70\%-os támogatási intenzitás mellett. Az önrész fedezésére a cég egy svájcifrank-alapú hitelt vett fel, és mivel ekkor még önkormányzati hatáskörben volt az ármegállapítás, ezért a törlesztés biztosnak tűnt. A 2008-as válság után azonban a devizahitel törlesztőrészletei nagyon megemelkedtek, a bank pedig először felmondta a hitelt, majd egy tárgyalássorozat után további biztosítékok bevonása és a hitel forintosítása után átstrukturálta azt. A víziközmú-ágazat reformja és a rezsicsökkentés miatt azonban a cég nagyon nehéz helyzetbe került: „[n]agyon katasztrofális ilyen értelemben a helyzet, tehát most már a bank egy kicsit lenyugodott, de maga a helyzet pont a veszteségeink miatt továbbra is Damoklész kardjaként itt van fölöttünk. Ez a hitel 2026-ban jár le." A hatósági árazás miatt a vízdíjak (és ezen keresztül a bevételek) emelésére nincs mód, a fogyasztás a népességcsökkenés miatt csökken, a kiadási oldalon viszont a növekvő adóterhek lerontják a cég mérlegét, amely emiatt folyamatos önkormányzati támogatásra szorul, és évek óta nem tud fizetésemelést adni, ami miatt folyamatosan humánerőforrás-problémákkal küzd. A cég helyzete nem egyedi, egy, a víziközmű-ágazatot elemző tanulmány is hasonló megállapításokra jutott az egész ágazat vonatkozásában (KPMG 2015). Ennek a közműcégnek az esete arra világít rá, hogy az önkormányzati adósságrendezés során az önkormányzati cégek adósságai nem lettek szanálva, ezek egyfajta extra költségvetési teherként nehezítik egyes önkormányzatok gazdálkodását. Ez egybevág az ÁSZ egyik 2019-es jelentésének megállapításával, amelyben 322 önkormányzatot vizsgáltak (Állami Számvevőszék 2019). A jelentés szerint „a városi önkormányzatok gazdálkodására kockázatforrást jelentett a többségi tulajdonú gazdasági társaságaik veszteséges müködése és kötelezettségeinek állománya, valamint a tartós részesedések állományának növekedése", mivel például mind 2015-ben, mind 2016-ban a vizsgált önkormányzatok múködési jövedelme kevesebb volt, mint a többségi tulajdonukban lévő gazdasági társaságaik kötelezettségállománya. Azaz az önkormányzati adósságkonszolidáció ebből a perspektívából nem volt teljes körű (Állami Számvevőszék 2019: 22).

A feladatelvonás és az adósságrendezés értékelése mellett a 2011-es államháztartási törvény és a stabilitási törvény, illetve a 2013-as államháztartási számvitelről szóló kormányrendelet ${ }^{4}$ értékelése is felmerült az interjúink során, mint amelyek megszabják a kereteit az önkormányzatok fiskális mozgásterének. Az ezeket meghatározó új irányelv rettentően megnehezíti az önkormányzatok eladósodását, viszont a múködési egyenleget az új feladatfinanszírozási rendszeren, illetve az új számviteli szabályokon keresztül stabilizálja. Az egyik önkormányzati pénzügyekkel foglalkozó hivatalnok így fogalmazott: „Azt látjuk, hogy mind bevételi, mind kiadási oldalon a források a müködésbe áramlanak, a fejlesztésben pedig keletkezik egy jelentős mesterséges

4 2011. évi CXCV. törvény az államháztartásról; 2011. évi CXCIV. törvény Magyarország gazdasági stabilitásáról, 4/2013. (I. 11.) Korm. rendelet az államháztartás számviteléről. 
hiány [...]. [Korábban] nagyon nagy feszültségek voltak, és az eladósodás nem véletlenül alakult ki az önkormányzatoknál. De legalább jogcím volt arra, hogy felhalmozásra is fordítsak forrásokat. Most ez a jogcím ezzel a tervezési metódussal kvázi megszünik." Az idézet nem feltétlenül a számviteli részletszabályozások kritikája miatt fontos, hanem azért, mert rámutat, hogy az önkormányzatok többsége - amelyek nem rendelkeznek számottevő helyi adóbevétellel - nagyon nehezen tudnak fejlesztési forrásokat kitermelni, illetve beruházni a mindennapi múködés biztosításán túl. Tehát míg a jelentősen lecsökkentett feladataikat többségükben el tudják látni, a jövőbeli pályájukat meghatározó fejlesztések terén már jócskán lecsökkent a mozgásterük. Ez a zsugorodó városok esetében valószínúleg hatványozottan igaz.

A már idézett hivatalnok ezt így fejtette ki: „A 2000-es években, és ez kormányfüggetlen volt, hosszú ideig voltak területi kiegyenlítést is szolgáló pályázatok. [...] Ezerféle nevük volt, és ezeket a megyei és regionális fejlesztési tanácsok osztották. Úgyhogy a kistérségek, akik ezekben a szervezetekben alapitók és résztvevők voltak, szavazóképesek voltak, megkötötték a saját jórossz, de helyi konszenzusukat, és ezeket a deregulált forrásokat ezekre a fejlesztésekre lehetett fordítani. Egy decentralizált döntési rendszerben. Most ezekre a feladatokra kétféle pénz van. Vagy a nagy uniós pályázatok, vagy pedig... úgyse tagadom le, na... vagy az év végi pofapénz. Tehát a [központi] költségvetés tartalékaiból az elmúlt években hagyománnyá vált, hogy nagyon nagy összegú egyedi támogatások kerülnek jóváhagyásra egyes településeknek."

A fejlesztési forrásokat érintő központosításról szóló sommás összefoglalót egy kicsit kibővítve az egyéb empirikus anyagokból szerzett tapasztalatokkal azt állíthatjuk, hogy az önkormányzatok fejlesztési mozgástere, azaz lényegében a települések jövőjét meghatározó beruházásokkal kapcsolatos mozgástér nagyjából négy nagy bevételi forráson alapul: a már említett EU-s forrásokon, illetve az év végi „pofapénzen” túl ide sorolhatjuk a helyi adóbevételeket (amelyek a hivatalnok városában az alacsony gazdasági aktivitás miatt nem jelentősek, így nem véletlenül hagyta ki a felsorolásból), illetve a közfoglalkoztatási programokat. Összességében tehát az önkormányzati rendszer központosítása feszesen és bizonyos megkötésekkel ugyan, de többségében biztosítja az önkormányzatok müködési költségeit, viszont a fejlesztés területén új kényszerekkel és csökkenő mozgástérrel szembesülnek. Az egyik interjúalanyunk ezt így összegezte, arra a kérdésre válaszolva, hogy melyek a város költségvetésével kapcsolatos főbb folyamatok: „Ha egy mondatba akarnám összefoglalni, akkor gúzsba kötve táncolunk.” A tanulmány további részében ezt a gúzsba kötést, azaz a fentebb említett négy területet és az ezek által nyitott lehetőségeket/kényszereket elemzem részletesebben.

\section{Közhatalmi bevételek, helyi adók}

A rendszerváltás során az önkormányzati decentralizáció egyik alapelve volt, hogy az önkormányzatok a kapitalista viszonyok kiterjesztésével a területükön végzett gazdasági aktivitás után szedett adókból részesülhetnek, ezzel is ösztönözve őket a „vállalkozói” logika átvételére (Vigvári 2007: 179). Ennek a gondolatmenetnek a része volt például, hogy 1990-ben a frissen bevezetett személyi jövedelemadó (szja) 100\%-a az 
önkormányzatok költségvetésébe áramlott. Ez azonban már az 1990-es évek legelején, a rendszerváltás utáni gazdasági válság kontextusában megváltozott, és a decentralizációs időszak egészében a kezdeti elképzelésekhez képest egyre jelentéktelenebbé vált az ilyen típusú adók önkormányzati fejlesztésekre történő átcsoportosítása, míg végül 2012 óta az szja szinte teljes egészében a központi kormányzatnál marad. A 2010 utáni recentralizációs fordulat óta az adó típusú bevételek közül a helyi iparűzési adó (hipa) lett az önkormányzatok legjelentősebb bevételi forrása, amelyet fejlesztésekre fordíthatnának, a vizsgált városainkban azonban ez a teljes bevételhez képest rendre csak az 5-20\% közötti sávban mozog (az országos átlag 2016-ban 9,7\% volt).

2. ábra: Négy város HIPA bevételei az összes bevétel százalékában

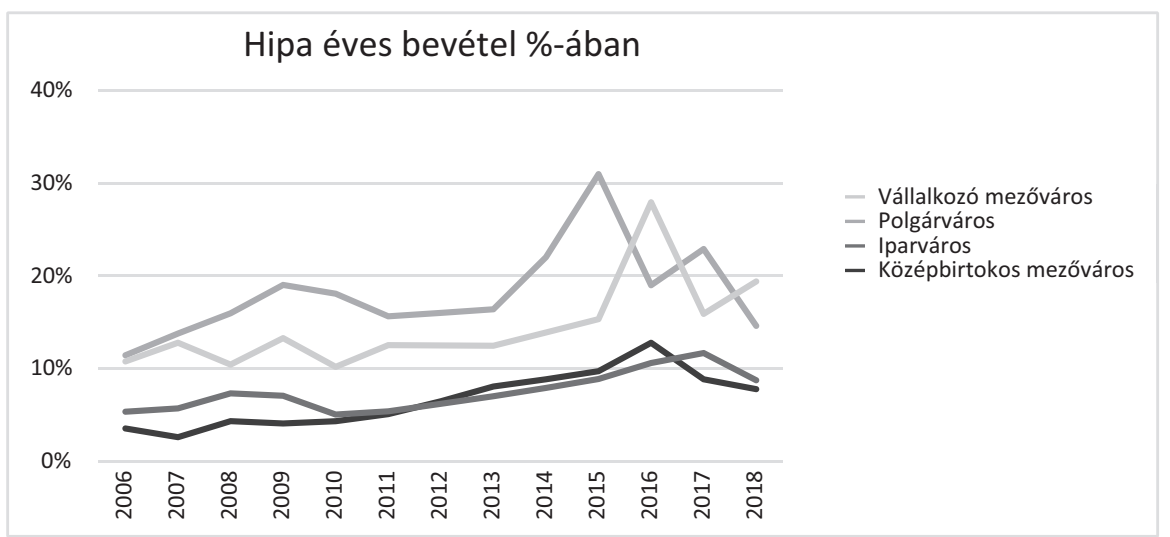

(Forrás: TEIR és zárszámadási rendeletek)

3. ábra: Négy város HIPA bevételei a közhatalmi bevételek százalékában

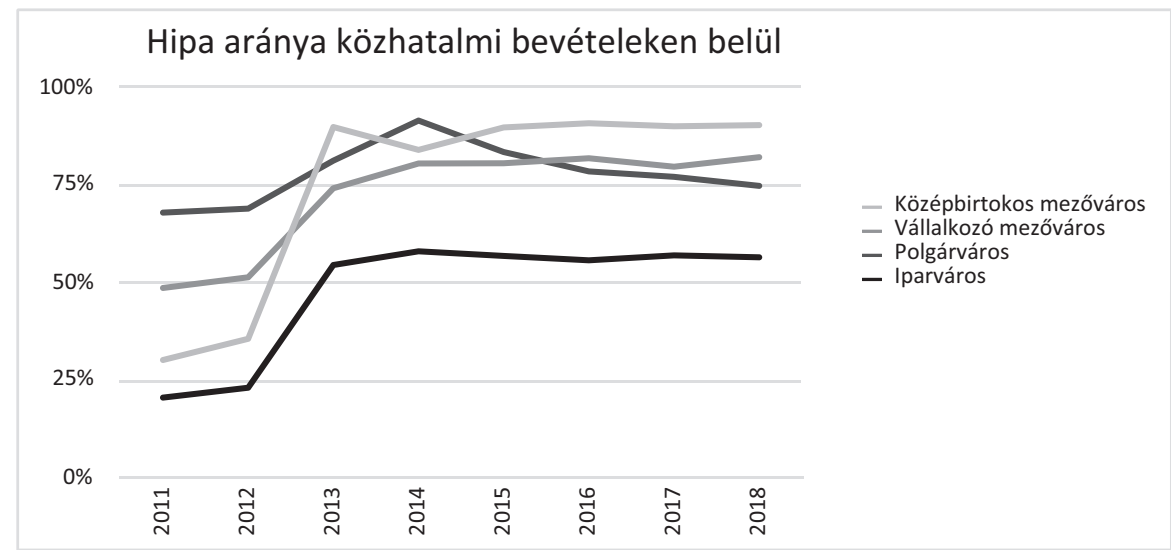

(Forrás: TEIR és zárszámadási rendeletek) 
A hipa mértéke azonban nagyon nagy mértékben függ az adott város és régió gazdasági fejlettségétől, és ennyiben az elmaradott, a rendszerváltás veszteseinek tekinthető régiókban található, zsugorodó városok különösen rossz helyzetben vannak. Ennek ellenére a 2. és a 3. ábrán láthatjuk, hogy a négy vizsgált városunk esetében az éves bevételekhez képest a hipa aránya egy város kivételével mindenhol nagyjából megduplázódott, míg a közhatalmi bevételek csoportján belül is minden város esetében sokkal dominánsabbá vált, mint korábban. Ugyan a vizsgált időszakban nominális értékben is mindenhol nőtt a hipa értéke, tükrözve a 2010-es évekre jellemző gazdasági konjunktúrát, és ez a kép valamiféle növekvő önállóságot is sugallhatna, az interjúink árnyalják ezt a képet. Egyrészt még ha nominális értéken nőttek is a hipa-bevételek, ez sokszor a müködési költségek fedezését szolgálja, és a városok csak csekély mértékben tudják azt fejlesztésekre fordítani. Másrészt bár több új hazai vagy külföldi cég kezdett gazdasági tevékenységbe Magyarországon ebben az időszakban, ezek lokalizációja azonban erősen centralizált folyamattá vált. Több városvezető is panaszkodott, hogy nagyobb jelentőségú gazdaságfejlesztés csak ott történik, ahol országos jelentőségű politikusok tudnak lobbizni ezért. A vállalkozó mezővárosban, ahova nem kötődik ilyen országos jelentőségú politikus, például arról panaszkodott a helyi ipari park vezetője, hogy 2009 óta nem „küldtek” befektetőket a gazdaságfejlesztéssel foglalkozó budapesti székhelyű szervek. A középbirtokos mezővárosban viszont, ahonnan több országosan jelentős politikus is származik, több sikeres és sikertelen „kiközvetítés” is volt. A sikertelen próbálkozás esetében egyértelmú volt, hogy a központi támogatások mértéke döntött a helyszínválasztásban. „Voltak tárgyalások egy nagy céggel, hogy egy létezö üzembe beszállna, és akkor egy nagyobb volumenü üzemet hoznak létre. Nem nálunk dölt el, hogy nem itt valósult meg. Valószínúleg nagyobb állami támogatást kaptak máshol, mint itt. Én ezt gondolom." Amikor viszont sikerült állami támogatással két új céget is az ipari parkba vonzani, akkor az sem váltotta be a reményeket: „Gyakorlatilag ígértek egy 120 fös munkahelyteremtést, ebböl megvalósult 70 fó. Létrejött egy másik üzem. Itt is ígértek egy 70-80 embert, van most 30 ember körülbelül. Ez az, ami megvalósult az ipari parkon belül. Én ezt nagyon kevésnek tartom, megmondom öszintén."

A polgárvárosban és az iparvárosban igazán jelentős gazdasági beruházás a vizsgált időszakban nem valósult meg, a polgárvárosban még jelentősen csökkent is a hipa az elmúlt években az egyik jelentős cég átszervezése miatt. Sokatmondó, hogy az iparváros vezetői visszatérően arról beszéltek, hogy a város kitörési pontja a gazdasági problémákból egy központilag finanszírozott börtönépítési projekt lehetne, amely azonban szintén nem valósult meg végül. Ennek ellenére az iparváros sikeres vállalkozóival készített interjúkból az derült ki, hogy bár a város költségvetésének a perspektívájából a gazdasági konjunktúra nem tudta érdemben növelni a város mozgásterét, egyes vállalkozók szép egyéni sikereket tudtak elérni a gazdasági fellendülés, illetve az EU-s támogatások miatt. Ezek a középvállalkozói sikerek azonban nem tudtak olyan értelemben beépülni a város életébe, hogy érdemben befolyásolják 
a zsugorodó dinamikákat vagy az elvándorlást. Ez többek között annak is köszönhető, hogy a hipa ${ }^{5}$ és az egyéb helyi adók (pl. kommunális adó, építményadó) kiszabásának a mértéke törvényileg szabályozott, és ezért jelentős költségvetési változást csak egy új nagyvállalkozás tudna hozni még egy középváros esetében is.

Összességében tehát a vizsgált városok esetében a csökkenő költségvetési főösszeg miatt relatív egyre fontosabbá vált a hipa szerepe a városi költségvetésben, azonban a gazdasági fellendülés időszaka alatt sem tudott egyik helyen sem abszolút értelemben jelentős fejlesztési mozgásteret nyitni. Ezt a jelenséget a helyi adók törvényi szabályozása mellett az is megerősítette, hogy a gazdaságfejlesztés intézményrendszere szintén erősen centralizált, és az országos jelentőségû politikusok helyi kötődései és lobbiereje határozza meg, nem pedig egy világos gazdaság- és területfejlesztési elvrendszer 6 . Másként fogalmazva: bár első ránézésre a hipa relatív költségvetési súlyának növekedése egyfajta vállalkozói fordulatot is implikálhatna, valójában nem ez történik, hiszen a gazdaságfejlesztés területét is érintik a centralizációs törekvések. Ez kis részben a - hipa beszedésének szempontjából kulcsfontosságú - ipari parkok centralizációjában (Szarka 2017), nagyobb részben pedig a vállalatokkal való tárgyalások centralizásában érhető tetten. Több interjúalanyunk szerint is a politikai klientalizmus hálózatai szabják meg a gazdaság- és területfejlesztés jelentős folyamatait. Az egyik város ipari parkjának vezetője így fogalmazott: „Akkor lesz Magyarországon igazi verseny, ha nem lesz egy ilyen központi szürő, ahol eldöntik, hogy [egy külföldi cég] ide mehet vagy oda mehet."

\section{Az európai uniós projektek világa}

A középvárosi önkormányzatok mozgástere szempontjából a helyi adóbevételekhez képest sokkal fontosabb az EU-s források szerepe. A 2014-2020-as költségvetési időszakban a vizsgált városokban az önkormányzatok által elnyert EU-s támogatások mértéke nagyjából a teljes költségvetésük 8,5\%-át tette ki. Másképp számolva, ugyanebben a periódusban a 2014-2018 közötti átlaggal számolva az átlagos éves költségvetésük 36-97\%-át kapták meg EU-s fejlesztési forrásként. Az interjúk szerint jelentősebb fejlesztési beruházások évek óta szinte kizárólag ezekből a forrásokból tudnak megvalósulni kis- és középvárosi szinten. Fontos megemlíteni, hogy ezeknek a beáramló EU-s forrásoknak nagyon nagy a ciklikussága: egy 7 éves EU-s ciklus tipikusan „farnehéz”, azaz az utolsó években sokkal nagyobb a kifizetések mennyisége, mint a ciklus elején. Volt olyan város, ahol az egyik évben a bevételek nagyjából fele EU-s támogatás volt. A mostani EU-s költségvetési ciklus esetében annyi az eltérés, hogy - a többi kelet-európai tagállamtól eltérően - a kormányzat erőteljes célja volt 2017-ig lebonyolítani a kifizetések legnagyobb részét. Emiatt most „papíron” már 100\% fölötti a magyar abszorpciós adat, valójában azonban az

5 A hatályos jogszabályok szerint az önkormányzatok által kiszabható hipa felső határa a vállalkozás adóalapjának 2\%-a.

6 Bár ilyen dokumentumok elvileg léteznek (pl. OFTK), de ezek jelentősége egyik interjúnk során sem merült fel. 
EU-s fejlesztési pénzek elköltése jelenleg is zajlik. Ez magyarázza az egyes városok esetében látható kiugró éves adatokat az 1. ábrán.

Az EU-s források célzása azonban szintén egyre inkább központosított lett az elmúlt évtizedben. Az önkormányzati adósságrendezéssel, illetve az önkormányzati rendszer centralizációjával párhuzamosan zajlott az EU-s fejlesztési források menedzseléséért felelős hazai intézményrendszer átalakítása. Ennek az átalakításnak is a politikai kontroll volt az egyik fő jelszava. 2014-ben megszűnt a Nemzeti Fejlesztési Ügynökség (NFÜ) és a VÁTI is: mindkettő olyan jelentős szakmai mühely volt, amely az EU-s fejlesztések programozásában, illetve az elköltés menedzselésében és monitorozásában kiemelt szerepet játszott, a jelenlegihez képest relatív autonóm módon. Ebben az időszakban szúntek meg a regionális fejlesztési ügynökségek is, amelyek bizonyos esetekben hatékonyan elő tudták segíteni a projektek területspecifikus megvalósítását. Ezek helyét egyrészt a minisztériumok alá rendelt irányító hatóságok vették át, másrészt a politikailag rövidebb pórázon tartott új tervezőintézetek (2014-ig a rövid életű Nemzetgazdasági Tervezési Hivatal [NTH], majd utána a Nemzetstratégiai Kutatóintézet).

A nemzetgazdaságilag is igen jelentős gazdasági szereppel bíró EU-s transzferek centralizálásán keresztül az EU-s források célzása is sokkal jobban belesimult a megerősödő helyi politikai hegemóniába (Gerőcs-Jelinek 2018). A 2014-2020-as időszak erősen gazdaságfejlesztési orientációjú lett, amit megerősítettek a vizsgált városok vállalkozóival készített interjúk is. Az időszak gazdasági konjunktúrájának egyik meghatározó forrását ezek a vállalkozásokat támogató fejlesztési források jelentik. Emellett azonban a városi önkormányzatok is jelentős forrásokhoz jutottak, döntően a Terület- és Településfejlesztési Operatív Programon (TOP) keresztül, amelyeket leginkább városfejlesztési, energiahatékonysági, kulturális és szociálisan célzott beavatkozásokra tudták fordítani. Míg ezek nagy része ellensúlyozni tudta a központosítással együtt járó bevételkiesést, addig a szociálisan célzott beruházások - zömmel a szociális városrehabilitáció típusú beavatkozások a szegregátumokban - annyiban különlegesek voltak, hogy korábban soha nem látott összegú fejlesztéseket tettek lehetővé a települések leghátrányosabb részein. Ahogy ezt Virág Tünde (2020) részletesebben is kifejti, ezek a szociálisan célzott, az EU által finanszírozott beruházások sokszor a helyi városvezetők kontrollfunkcióját erősítették, amennyiben a város marginalizált lakosságának az életkörülményeit tudták megváltoztatni egy tipikusan paternalista keretben (vö. Jelinek 2017; Jelinek-Pósfai 2019; Jelinek-Virág 2019).

Lényeges, nem szándékolt mellékhatása az EU-s lépték növekvő szerepének a középvárosi fejlesztésekben, hogy minden általunk ismert kontextusban kialakult egy olyan helyi csoport, amelyet „projektosztálynak” nevezhetünk (vö. Czibere-Gerő-Kovách 2017; Füzér 2017). Ez a csoport az önkormányzat hivatali dolgozóiból, a városfejlesztéssel foglalkozó önkormányzati cégek dolgozóiból, pályázatírókból, tanácsadókból, illetve pályázatokban részt vevő civilekből áll, akik sokszor az önkormányzati költségvetés jelentős részének (akár évi 5-10\%) az elköltésében vesznek részt. Bár au- 
tonómiájuk erősen korlátozott - az országos szintű keretrendszerek (pl. az operatív programok jelentette megkötések), illetve a helyi politikusok által -, egyes helyi fejlesztési projektek megvalósítására mégis jelentős hatást tudnak gyakorolni. Ennyiben az önkormányzatok számára rendelkezésre álló mozgástér kihasználásában - különösen a szociálisan elvileg érzékeny beavatkozások lefolytatásában - nagy szerepük van. Egészen pontosan a helyi projektosztály és a helyi döntéshozók közötti viszony központi tényező a középvárosi szegénység kormányzásának kérdésében.

A tapasztalataink alapján az is szembetûnő, hogy a helyi elitek (amelynek része a helyi projektosztály is) milyen erős befolyással bírnak ezeknek a fejlesztési forrásoknak a becsatornázásában. Az interjúk alapján az lett a benyomásunk, hogy a rendszerváltás óta tipikusan „alulfejlesztett”, zsugorodó középvárosi önkormányzatok a beérkező EU-s forrásokat egyfajta történelmi kompenzációként kezelik, amelylyel gyakran a helyi középosztály pozícióit próbálják erősíteni, és ezzel nem egyszer még inkább intézményesíteni a helyi társadalmi egyenlőtlenségeket, megerősítve a marginalizáltakat elválasztó szimbolikus határokat.

Egy tipikus példa erre az egyik általunk vizsgált városban az egyik zsákutcaszerűen elhelyezkedő szegregátum felújítása, a helyben lakók költöztetéseken keresztüli szelektálása, a környék bekamerázása, illetve a helyi ellenőrzést segítő szociális munka kiszervezése az egyik egyházi karitatív szervezetnek. Az ilyen típusú beavatkozásokon keresztül a korábban gyakran társadalmi „senki földjeként” elkönyvelt szegregátumok nem a városi társadalom vérkeringésébe lesznek integrálva, hanem pusztán a helyi társadalmi problémák ellenőrzése és a város többségi társadalma számára elviselhető szintűvé tompítása történik. Természetesen vannak kivételek valóban társadalmilag érzékeny projektek formájában, ezek azonban a limitált EU-s források, illetve a rendkívül komplex EU-s bürokrácia miatt nem tudják jelentősen, rendszerszinten javítani az amúgy a tágabb társadalom- és gazdaságpolitikai eszközökkel szisztematikusan gerjesztett társadalmi polarizációt.

\section{Közfoglalkoztatás és a munkaalapú társadalom}

Az EU-s finanszírozásból megvalósuló fejlesztési projektek mellett a középvárosok esetében az elmúlt évtizedben felfutó közmunkaprogramok biztosították a legjelentősebb többletforrást. A legtöbb esetben ezeket felhasználva az önkormányzatok a területükön élő marginalizált lakosság foglalkoztatásán keresztül beruházásokat is meg tudtak valósítani. Az alábbi, 4. ábrán látható az általunk vizsgált városokban közmunkaprogramban foglalkoztatottak létszáma a teljes városi lakossághoz viszonyítva. Mivel a munkaképes lakosság nagyjából a fele a teljes lakosságnak, ezért a legkirívóbb esetben a közmunkaprogramok csúcsának számító 2015-ös évben az iparvárosban nagyjából minden tizedik munkaképes korú helyi lakos részt vett a közmunkaprogram valamelyik részében. Ugyanebben az évben a város bevételeinek 20\%-át adták a közfoglalkoztatással összefüggő támogatások. Bár más városok esetében nem mindig találtunk ilyen kiugró számokat, de a fenti összeg jelzi a köz- 
munkaprogramok bevezetésével az önkormányzat változó funkcióit, amennyiben egyes években teljes bevételének akár az ötödét az alapján kapja, hogy az alacsony osztályhelyzetű helyi lakosokat munkával lássa el.

4. ábra: Közfoglalkoztatottak aránya a teljes népességhez képest négy városban

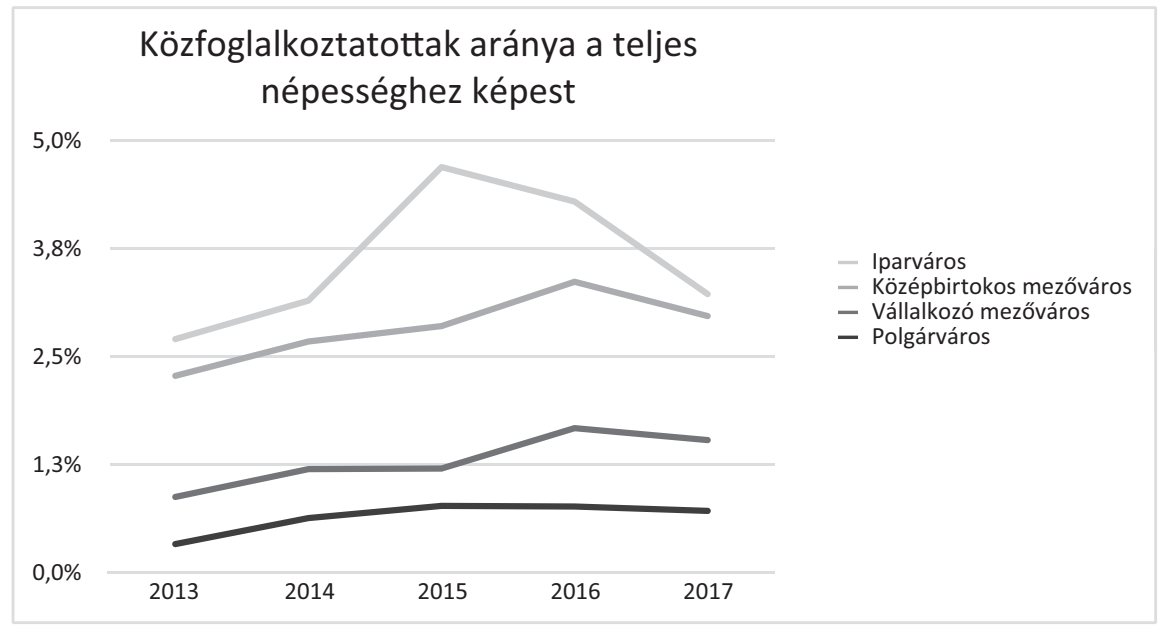

(Forrás: TEIR)

Ez a folyamat a helyi munkaerőpiac átalakítása mellett hatott az önkormányzati intézmények tevékenységére is, ugyanis a közmunkaprogramokra szánt források egy részét városfejlesztési célokra is el lehetett költeni (Koltai 2018: 99). Több olyan önkormányzati vezetővel is készítettünk interjút, aki ritka lehetőségként értékelte, hogy a város intézményeit olyan gazdasági tevékenységekre állítsák rá, amelyek csökkenthetik a piaci alapon kiszervezendő munkák körét, és ezzel a városba áramló erőforrásokat helyben tartják. Ilyen megfontolásból volt, ahol élelmiszeripari üzemeket hoztak létre, hogy a városi intézmények igényeit ki tudják elégíteni, volt, ahol a városüzemeltetési feladatok egy részét tudták megoldani „házon belül”, és volt, ahol a város energiaellátását szerették volna saját erőből megoldani. Ezek a tervek rámutatnak a közmunkaprogramok által nyújtott nagyobb önkormányzati mozgástérre (Váradi 2016).

A tágabb munkaerőpiaci folyamatokat is figyelembe véve azonban az látszik, hogy a közmunkaprogram igazán lényeges fejlesztési potenciált csak 2015 környékén és csupán néhány évig tudott nyújtani, amíg a szelektív kivándorlás és az EU-s források által is fútött gazdasági konjunktúra miatt a piaci cégek fel nem szívták a munkaerő nagy részét. Ezután több helyen is úgy értékelték a közmunkát irányító hivatalnokok a helyzetet, mint például a polgárváros egyik magas rangú vezetője: „Közhasznúból van elég, csak olyan emberek vannak, akikkel nem lehet mit kezdeni. Ha azt mondom neki, hogy fessél végig egy játszótéren nyolc órát, akkor biztos, hogy nem fog 
tudni. Szondáztatás van reggel, szondáztatás van este, hogy a felét elküldjük, mert már részeg. Kiönti a festéket, ellopja a festéket, tolja az ecsetet, tehát nem érdekelt abban... jó, a másik oldalon meg ott van egy 50.000 forintos fizetés, ami az éhhalálhoz sem elég."

A fenti interjúidézet nemcsak arra világít rá, hogy a közmunkaprogramok 2017 után egyre kisebb valós fejlesztési potenciállal bírtak a vizsgált városok szemszögéből, hanem arra is ráirányítja a figyelmet, hogy a közmunkaprogramoknak többek között nagyon erős kontrolláló funkciója volt a helyi marginalizált rétegek szempontjából (Kovai 2016, 2019). Az ezzel kapcsolatos városvezetői narratívák visszatükrözték a központi kormányzat narratíváját, amely 2010 óta a jóléti politikák legtöbbjét minimalizálta, és helyette a munkaalapú társadalom eszméjére alapozta a szociális ügyeket érintő közpolitikáit. A vállalkozó mezőváros egyik befolyásos gazdasági szereplője például az alábbiakkal jellemezte a közmunkásokat: „Tehát foglalkozni kell velük, mert egyébként munkaerö-tartalék is egyben. Tehát csak a kimüvelt emberföt, a képzett, szorgalmasat. Jó, hogy 14 évesen már férjhez megy a lány, én nem tudom, hogy mi van, én ezeket a hátterü dolgokat, nem is akarok róla beszélni. De majd csak fejlődnek. Hagyni kell öket magukban, és akkor jönnek dolgozni, segitenek, vagy csinálják; akkor munkára kell őket tanítani. De munkakultúrájuk sincs." Ez a narratíva is jelzi, hogy a gazdasági konjunktúra ellenére a marginalizált népesség helyi kontrollja az EU-s finanszírozású beruházások mellett a közmunkaprogramon keresztül tudott megvalósulni (Kovai-Vigvári 2020). Ezzel ambivalens módon azt is állíthatjuk, hogy míg 2010 után az önkormányzatok mozgástere a legtöbb területen beszúkült, addig az alacsony osztályhelyzetúek kontrolljával kapcsolatban sokkal szabadabb kezet kaptak, mint korábban. Ezt a folyamatot nevezem a kontrollmechanizmusok és az autoriter kormányzás „leszivárgásának”.

\section{„Pofapénz"}

Végezetül térjünk vissza az egyik interjúalanyunk által „pofapénznek” nevezett jelenséghez. A fentebb elemzett bevételi források, azaz a 2010-es évek során egyre növekvő hipa-bevételek, az EU-s fejlesztési források, illetve a közmunkaprogrammal kapcsolatos bevételek csak részben ellensúlyozták a központosítás miatt megcsappanó bevételeket. Az általunk vizsgált négy városban - és valószínúleg a hasonló helyzetben lévő zsugorodó kis- és középvárosokban - ezek sem voltak elegendőek ahhoz, hogy az átalakított önkormányzati finanszírozás strukturális feszültségeit kezeljék. A fejlesztésre rendelkezésre álló, fentebb említett források nagy részét csak adott területeken lehet befektetni, és bizonyos alapvető infrastrukturális fejlesztésekre vagy bizonyos években a múködési költségekre alig van megfelelő forrás. A "gúzsba kötés” adott esetben költségvetési hiányhoz is vezethetne, amelyet a jelenlegi rendszerben hitelekkel nagyon nehéz ellensúlyozni. Az interjúalanyaink szerint ezt a feszültséget hivatott kezelni a „pofapénz” intézménye. A „pofapénz” leginkább a „rendkívüli önkormányzati támogatás” formális kategóriájának felel meg, amelynek teljes összege a 2020-as költségvetésben 8 milliárd forint, azaz a teljes önkormányzati szektor szempontjából elhanyagolható. A költségvetés egyéb fejezeteiben, 
illetve év végén a maradványok elköltésének időszakában azonban számos egyéb, konkrét településhez köthető projekt kap célzott központi támogatást. Ezt a formális kategóriákkal nehezen leírható, nagyjából azonban minden önkormányzati vezető által ismert jelenséget nevezzük „pofapénznek”. De mit is jelent ez pontosan?

Interjúalanyunk így jellemezte a folyamatot: „Itt nem pályázat kerül benyújtásra, hanem íródik egy A/4-es levél, ami elmegy 3-4 féle e-mail címre meg 3-4 féle postacímre, és utána polgármester úr - volt országgyúlési képviselői kapcsolatait meg pártkapcsolatait figyelembe véve - beül a céges autóba, fölmegy Pestre. Hol itt lobbizik, hol ott lobbizik."

A gazdaságfejlesztéshez hasonlóan itt is nagy jelentősége van, hogy vannak-e az adott városhoz kötődő országos jelentőségű politikusok, és nekik mekkora a lobbiereje. Ez a mechanizmus újabb bizonyítékul szolgál a klientalizmus kiépülésére és a helyi önkormányzatok központi kormányzattól való erősödő függésére. Még a sikeres lobbizás sem feltétlenül jelenti azonban a költségvetési feszültségek teljes körű megoldását. Az egyik költségvetésért felelős hivatalnok szerint: „Tehát a költségvetés tartalékaiból, az elmúlt években hagyománnyá vált, hogy nagyon nagy összegü egyedi támogatások kerülnek jóváhagyásra egyes településeknek. Megmondom öszintén, hogy ezzel egyetlen baj van. Hogy egy-egy koncentrált területre nagyon nagy összeget hagynak jóvá, amiből ott komplex fejlesztést kell végrehajtani. [...] Ebböl az összegböl, ha a városüzemeltetô cég megkapná ezt, akkor nagyjából a közúthálózat egyharmadán meg lehetne csinálni a kátyúzást. És nem kéne szinte nullára lerongyolódni egy úthálózatnak, hogy utána már indokolt legyen egy koncentrált, nagy felújítás."

Bár sem a „pofapénz”, sem a „Pesten lobbizás” nem teljesen új jelenség, de az interjúalanyaink beszámolója szerint ez a fajta politikai tevékenység lett az egyik fontos befolyásoló tényezője egy adott középváros sikerességének. A léptékek politikai-gazdaságtani irányzatához nyúlva azt mondhatjuk, hogy az erőforrások elosztásának kontrollálása 2010 után egyre jobban a központi kormányzat felügyelete alá kerül, ami egyben át is írja az önkormányzat és a központi kormányzat között lévő korábbi viszonyokat. Ennek az új korszaknak a kulcsszava a kontroll.

\section{Konklúzió}

Az elmúlt időszakban a középvárosi önkormányzatok mozgástere különböző okok miatt az eddigieknél is tovább szúkült. A 2008 utáni gazdasági világválság, illetve a 2010 utáni földcsuszamlásszerű hazai politikai változások következményeképpen a központi kormányzat és a városi önkormányzatok közötti viszony átalakult, és az előbbi sokkal erősebb kontrollt tud kifejteni az utóbbira. Ez a megváltozó viszony a tágabb gazdasági-politikai reformok része, és jól illeszkedik az újonnan színre lépő elitblokknak az új hegemónia megteremtésére irányuló kísérleteihez (Éber et al. 2019).

A kontroll azonban nem csak ebben az értelemben kulcsszó a jelenlegi időszakban: míg a helyi önkormányzatokat a központi kormányzat köti gúzsba, addig a helyi önkormányzatok a területükön élő állampolgárok, legalábbis az alacsonyabb 
státuszú, kiszolgáltatottabb állampolgárok gúzsba kötése felé mozdulnak el. Azok a területek, ahol a települési önkormányzatok mozgástere nőtt az utóbbi években, leggyakrabban a helyi szegénység kormányzásához, illetve a helyi szegények potenciális kontrolljához kötődik. Összességében tehát az önkormányzatok „lengéscsillapító”, „kipárnázó” szerepe - amelyet már az 1990-es és 2000-es évek elemzésekor is azonosítottak (Szalai 2007) - erősödik a gúzsba kötés folyományaként. Ez a kipárnázás azonban most nem a decentralizációs, hanem éppen a centralizációs tendenciákhoz kötődve müködik, és a korábbi időszakhoz hasonlóan arra irányul, hogy a helyi társadalmi feszültségek ne érjenek el kritikus szintet.

Ennek a „kipárnázó” funkciónak az elsődleges eszközei a közmunkaprogramok és a szociálisan célzott EU-s fejlesztések, amelyek a szűkös fejlesztési források legfontosabb elemei a zsugorodó középvárosok szempontjából. Ezek egy szúk pályán ugyan, de lehetőséget adnak a helyi feszültségek kezelésére és kontrollálására. Ezzel párhuzamosan azonban a tágabb recentralizációs törekvések és az önkormányzati szféra szanálása a központi kormányzattól való függés szisztematikus erősödését hozta magával. Bár az elmúlt évtized gazdasági konjunktúrája miatt a helyi adóbevételek relatív fontossága nőtt, ez részben a költségvetési főösszeg drasztikus csökkenésével, illetve a különböző funkciók elvonásával magyarázható. A helyi adóbevételek tehát a legtöbb önkormányzat - és különösen a zsugorodó kis- és középvárosok - esetében továbbra sem nyújtanak számottevő költségvetési mozgásteret.

Az önkormányzatok mozgásterének átalakulása nem kizárólag a zsugorodó városokat érinti, hanem szinte a teljes magyarországi önkormányzati rendszert, amelyet érdemes lenne további kutatásokkal elemezni. Jelen tanulmány szempontjából a leglényegesebb momentum ebből az általános tendenciából az, hogy a zsugorodó városok egy ilyen politikai, gazdasági és intézményi átalakulás közben még kiszolgáltatottabb helyzetbe kerülhetnek, mint a nem zsugorodó települések. A zsugorodó városokra ugyanis inkább jellemző a helyi adóbevételek szúkössége, a munkaerőpiaci anomáliák és a térbeli-társadalmi polarizáció egyéb negatív következményei.

Mindezeket figyelembe véve azt látjuk, hogy a zsugorodó középvárosi önkormányzatok jelenlegi mozgástere rendkívül szűkös ahhoz, hogy a zsugorodó tendenciákat ellensúlyozni tudják. Különösen igaz ez abból a perspektívából nézve, hogy a magyarországi kis- és középvárosi zsugorodás kiváltó okai olyan tágabb strukturális mozgások eredményei, mint például a rendszerváltás, majd a 2008-as válság utáni gazdasági (és különösképpen az ipari szektorra jellemző) átrendeződés, az európai munkaerőpiac megnyílása a magyar munkavállalók előtt a 2004-es EU-csatlakozás után, a kisvárosi, illetve tágabban a vidéki (egészségügyi, oktatási, kulturális, közlekedési stb.) infrastruktúra szelektív leépülése vagy tágabban a növekvő térbeli és társadalmi egyenlőtlenségek. Az elmúlt évtizedben zajló országos közpolitikai reformok ezeket a kiváltó okokat nem tudták megváltoztatni, sőt a legtöbb esetben tovább gerjesztették a folyamatot. Így az önkormányzati intézményrendszer elmúlt évtizedekben végrehajtott átalakítása, azaz a kormányzás központosítása csak nagyon korlátozott területeken 
adott nagyobb mozgásteret a helyi döntéshozóknak, és általánosságban inkább „gúzsba kötötte” őket. Azok a területek viszont, ahol inkább növekedett a mozgástér, meglátásom szerint nem alkalmasak a városi zsugorodás sikeres megállításához vagy a „helyes méret megtaláláshoz”. Ezek a területek tipikusan a helyi alsóbb társadalmi rétegek kontrollálásához adnak segítséget, így végső soron az országos léptéken kialakuló kontrollfunkciók „leszivárgását” azonosíthatjuk.

\begin{abstract}
The political economic approaches of urban shrinkage highlight the importance of how the room for manoeuvring of urban governments is shaped by broader, multi-scalar, structural processes. Through the example of the budgetary processes of four Hungarian towns, this article analyses the ways in which smaller cities can influence their future development trajectory. The first section of the article provides a short summary of recentralizing the local governmental system in Hungary in the last decade. While local governmental debt was taken over by the central government around 2014, the tasks and the budgets of local governments were curtailed at the same time. This results in a larger control of the central government over the local governments. While the local governmental budgets decreased, the relative increase of the weight of local taxes does not result in the broadening of the space for manoeuvring of local governments, mainly because of centralizing the institutions of economic development. Even though EU funds and the new public work scheme significantly contributed to local governmental budgets, the specific way how they were allocated and targeted resulted in the increasing control of local marginalized populations. Within the article this process is called as the „trickle down” mechanism of control. Furthermore, the phenomenon of "money-for-the-buddy” sheds light on the fact that the structural tensions present in the Hungarian local governmental system is not managed with formal procedures, but rather with informal arrangements and through the lobbying of local politicians. All in all, these tendencies show that the room for manoeuvring of the local governments of shrinking smaller cities is becoming narrower, and thus the potential modification of their shrinking tendencies is dependent upon broader political and economic changes.
\end{abstract}

Keywords: urban shrinkage, local governmental budgeting, urban governance, centralization, control

\title{
Irodalom
}

Aalbers, M. B. - Bernt, M. (2018): The political economy of managing decline and rightsizing. Urban Geography, 40(2): 165-173. DOI: https://doi.org/10.1080/027 23638.2018.1524654

Állami Számvevőszék (2019): Önkormányzatok pénzügyi monitoring alapján végzett ellenörzése. A városi önkormányzatok gazdálkodásának fenntarthatósága (19017-es Jelentés). Budapest. https://asz.hu/storage/files/files/jelentes/2019/19017.pdf (utolsó letöltés: 2020.06.01.)

Bernt, M. (2015): The limits of shrinkage: Conceptual pitfalls and alternatives in the discussion of urban population loss. International Journal of Urban and Regional Research, 40(2): 441-450. DOI: https://doi.org/10.1111/1468-2427.12289

Bethlendi A. - Lentner Cs. (2019): A magyar önkormányzati eladósodás és válságkezelés nemzetközi összehasonlításban. Közgazdasági Szemle, 66(10): 1013-1030. DOI: http://dx.doi.org/10.18414/KSZ.2019.10.1013 
Bird, R. M. - Wallich, C. I. - Péteri, G. (1995): Financing local government in Hungary. In Bird, R. M. -Ebel, R. D. - Wallich, C. I. (eds): Decentralization of the Socialist State. Washington: The International Bank for Reconstruction and Development - The World Bank, 69-116.

Coppola, A. (2019): Projects of becoming in a right-sizing shrinking City. Urban Geography, 40(2): 237-256. DOI: https://doi.org/10.1080/02723638.2017.1421 391

Czibere I. - Gerő M. - Kovách I. (2017): Újraelosztás és integráció. In Kovách I. (szerk.): Társadalmi integráció: Az egyenlōtlenségek, az együttmúködés, az újraelosztás és a hatalom szerkezete Magyarországon. Pécs: MTA TK, 51-116.

Czirfusz M. - Jelinek Cs. (2019): Az önkormányzatok mozgástere a lakhatási szegénység enyhítésében. In Jelinek Cs. (szerk.): Éves jelentés a lakhatási szegénységrôl 2019. Budapest: Habitat for Humanity Magyarország, 77-91.

Csiszárik-Kocsir Á. (2008): A magyar helyhatóságok eladósodása az ezredforduló után. Tér és Társadalom, 22(4), 81-95.

Éber M. Á. - Gagyi Á. - Gerőcs T. - Jelinek Cs. (2019): 2008-2018: Válság és hegemónia Magyarországon. Fordulat, 26: 28-75.

Füzér K. (2017): A projektesitett város: Részvételi városfejlesztés az ezredfordulós Pécsett. Pécs: IDResearch Kft. / Publikon Kiadó.

Gerőcs T. - Jelinek Cs. (2018): A Nemzeti Együttmúködés Rendszere az Európai Unióban. Eszmélet, 118: 12-33.

Hackworth, J. (2015): Rightsizing as spatial austerity in the American rust belt. Environment and Planning A, 47(4): 766-782. DOI: https://doi.org/10.1068/ a140327p

Heclo, H. - Wildavsky, A. (1981): The Private Government of Public Money. London: Macmillan.

Hegedüs J. - Péteri G. (2015): Közszolgáltatási reformok és a helyi önkormányzatiság. Szociológiai Szemle, 25(2): 90-119.

Horváth M. T. - Péteri G. - Vécsei P. (2014): A helyi forrásszabályozási rendszer magyarországi példája, 1990-2012. Közgazdasági Szemle, 61(2): 121-147.

Jelinek, Cs. (2017): Uneven development, urban policy making and brokerage. Urban rehabilitation policies in Hungary since the 1970s. PhD-értekezés. Budapest: Central European University.

Jelinek, Cs. - Pósfai, Zs. (2019): Reproducing socio-spatial unevenness through the dualization of policies in the domain of housing in Hungary. In Lang, T. Görmar, F. (eds.): Local and regional development in times of polarization. Re-thinking spatial policies in Europe. Singapore: Palgrave Macmillan, 197-223. https://link. springer.com/content/pdf/10.1007\%2F978-981-13-1190-1_9.pdf (utolsó letöltés: 2020.06.01.) 
Jelinek, Cs. - Virág, T. (2019): Development brokers and place-based projects in deprived urban neighbourhoods: The case of Pécs, Hungary. Justice Spatial Spatial Justice, (10): 1-22.

Jelinek Cs. - Virág T. (2020): Zsugorodó városok és társadalmi egyenlőtlenségek Magyarországon. Szociológiai Szemle, 30(2): 4-26.

Józsa V. (2016): A magyarországi regionalizmus egy gyakorlati szakember szemével. Tér és Társadalom, 30(1): 37-55. DOI: https://doi.org/10.17649/tet.30.1.2731

Koltai L. (szerk.) (2018): A közfoglalkoztatás hatása a helyi gazdaságra, helyi társadalomra. Budapest: Hétfa.

Kovai C. (2016): Önellátó függőség. In Kovács K. (szerk.): Földből élők: Polarizáció a magyar vidéken Budapest: Argumentum, 130-153.

Kovai, C. (2019): Permanent wage labour as a norm: Workfare policy and everyday experiences of precariousness in a small Hungarian former industrial town. Socio.Hu, 7: 143-161. DOI: https://doi.org/10.18030/socio.hu.2019en.142

Kovai C. - Vigvári A. (2020): Befejezetlen proletarizáció? A vidéki munkaerő-tartaléksereg Magyarországon a 2008-as válságot követően. Tér és Társadalom, 34(3): 68-89. DOI: http://doi.org/10.17649/TET.34.3.3284

Kováts B. (2016): Az önkormányzati hatáskörbe került lakhatási támogatások vizsgálata 31 önkormányzat példáján. Budapest: Habitat for Humanity Magyarország. http:// www.habitat.hu/files/Onkormanyzati_lakhatasi_tamogatasok_Habitat_0720. pdf (utolsó letöltés: 2020.06.01.)

KPMG (2015). A magyar víziközmü ágazat bemutatása - átfogó tanulmány. http:// www.maviz.org/system/files/kpmg-maviz_vizikozmu_agazati_helyzetkep_2._ kiadas_2015_aug.pdf (utolsó letöltés: 2020.06.01.)

Ladner, A. - Keuffer, N. - Baldersheim, H. (2016): Measuring local autonomy in 39 Countries (1990-2014). Regional and Federal Studies, 26(3): 321-357. DOI: https:// doi.org/10.1080/13597566.2016.1214911

Lentner Cs. (2014): A magyar önkormányzatok adósságkonszolidációja. Pénzügyi Szemle, (3): 330-344.

Pálné Kovács I. (szerk.) (2016): A magyar decentralizáció kudarca nyomában. Budapest-Pécs: Dialóg Campus Kiadó.

Péteri G. (szerk.) (1992): Költségvetési szociológia. Budapest: „Helyi demokrácia és újítások" Alapítvány.

Pitti Z. (2000): Állva maradt önkormányzatok. Kritika, 29(4): 2-6.

Scharle, Á. - Szikra, D. (2015): Recent changes moving Hungary away from the European Social Model. In Vaughan-Whitehead, D. (ed.): The European Social model in crisis. Cheltenham: Edward Elgar Publishing, 229-261.

Szalai J. (2004): A jóléti fogda - I. Esély, 15(6): 19-37.

Szalai J. (2005): A jóléti fogda - II. Esély, 16(1): 3-34.

Szalai J. (2007): Nincs két ország...? Budapest: Osiris. 
Szarka G. (2017): Országos Ipari Park Koncepció: az állami megoldás. NavigátorVilág, 1(11): 29.

Szikra, D. (2014): Democracy and welfare in hard times: The social policy of the Orbán Government in Hungary between 2010 and 2014. Journal of European Social Policy, 24(5): 486-500.

Váradi M. M. (2016): Értékteremtő közfoglalkoztatás periferikus vidéki terekben. Esély, 27(1): 30-56.

Vigvári A. (szerk.) (2005): Félúton: Tanulmányok a helyi önkormányzatok finanszírozási rendszerének továbbfejlesztési leherőségeiről. Budapest: TÖOSZ.

Vigvári A. (2007): Úton egy új vagyongazdálkodási paradigma felé. In Vigvári A. (szerk.): A családi ezüst. Tanulmányok az önkormányzati vagyongazdálkodás témaköréből. Budapest: Magyar Közigazgatási Intézet, 177-194.

Vigvári A. (2008): Szubszidiaritás nélküli decentralizáció. Néhány adalék az önkormányzati rendszer magyar modelljének korszerűsítéséhez. Tér és Társadalom, 22(2): 141-167.

Vigvári A. (2009): Atipikus önkormányzati eladósodás Magyarországon. Közgazdasági Szemle, 56(7-8): 709-730.

Virág T. (2020): Demográfiai polarizáció, térbeli és társadalmi marginalizáció két zsugorodó középvárosban. Szociológiai Szemle, 30(2): 27-49.

Wildavsky, A. (1975). The politics of the budgetary process. Boston: Little, Brown. 